\title{
DE VASTSTELLING VAN WINST UIT BEDRIJF VOLGENS HET BESLUIT OP DE INKOMSTENBELASTING 1941
}

Door de afkondiging van het Besluit op de Inkomstenbelasting 1941 in Verordeningenblad en Staatsblad is met ingang van 1 Januari 1941 eene nieuwe Inkomstenbelasting in werking getreden. Deze Inkomstenbelasting zal geheven worden volgens grondslagen, die sterk afwijken van de Wet op de Inkomstenbelasting 1914. De nieuwe grondslagen zullen aanleiding geven tot velerlei beschouwing.

Eenige opmerkingen ten aanzien van de wijze, waarop de winst uit bedrijf moet worden bepaald, mogen hier volgen.

In art. 7 van de Wet op de Inkomstenbelasting 1914 werd voor de opbrengst uit bedrijf alleen gesproken van ,winst", zonder dat aangegeven werd op welke wijze de winst moest worden berekend. In art. 10 werd slechts vermeld, wat onder bedrijfskosten moest worden verstaan. Elke methode van winstberekening, die niet in strijd was met ,,goed koopmansgebruik", werd overigens aanvaard. In de fiscale rechtspraak werd deze gedragslijn steeds gevolgd. Dit standpunt wordt in het Besluit op de Inkomstenbelasting 1941 verlaten.

Volgens art. 9 van het Besluit wordt voor belastingplichtigen, die regelmatig boekhouden met geregelde jaarlijksche afsluitingen, gepaard gaande met een inventarisatie, de winst gesteld op het verschil tusschen het zuivere bedrijfsvermogen bij het einde van het boekjaar en het zuivere bedrijfsvermogen bij het begin van dat jaar, dit verschil verhoogd met het geldelijk beloop van de onttrekkingen en verminderd met het bedrag van de ingebrachte kapitalen. Voor belastingplichtigen, die niet aan de genoemde eischen van regelmatig boekhouden voldoen, wordt ingevolge art. 12 de winst bepaald op het verschil tusschen de bruto winst en de bedrijfskosten, waarbij aangegeven wordt, wat onder bruto winst en bedrijfskosten moet worden verstaan.

In de praktijk zal dus voortaan een standpunt worden ingenomen, dat tegengesteld is aan dat van de Wet op de Inkomstenbelasting 1914. Voorheen was voor belastingplichtigen, die eene boekhouding voerden, die aan behoorlijke eischen voldeed, de winstrekening de grondslag voor de vaststelling van de bedrijfswinst. Indien de boekhouding onvoldoende was om tot de opstelling van eene winstrekening te komen, was men genoodzaakt de winst te bepalen door middel van het verschil in bedrijfsvermogen aan het begin en aan het einde van het boekjaar. - Het vroegere standpunt is volkomen juist te achten, daar alleen de winstrekening de gegevens kan verschaffen om de winst van het bedrijf volgens bedrijfseconomische beginselen vast te stellen.

$\mathrm{Bij}$ de nieuwe regeling wordt, wanneer eene regelmatige boekhouding wordt gevoerd - en dit is bij zaken van eenige beteekenis vrijwel altijd het geval -, niet de winstrekening als grondslag voor het bepalen van de winst genomen. Het Besluit Inkomstenbelasting brengt de vaststelling van de winst geheel binnen de grenzen van het bedrijfsvermogen. Ook het Besluit op de Winstbelascting 1940 kent voor de winstbepaling van naaml. vennootschappen e.a, het vermogen als uitgangspunt. Doordat de Winstbelasting eene voortzetting is van de vroeger geheven Dividenden Tantièmebelasting, waarbij als grondslag voor de winstbepaling werd genomen het verschil tusschen het aanwezige vermogen en het gestorte kapitaal, werd voor de Winstbelasting het winstprincipe van de D. en T. 
belasting overgenomen. - Wanneer bij het invoeren van de Winstbelasting over de op het overgangstijdstip aanwezige reserves nog belasting was geheven, zou men ten aanzien van de grondslagen voor de winstbepaling niet gebonden zijn geweest.

Voor het berekenen van het bedrijfsvermogen worden ingevolge het $\mathrm{Be}$ sluit Inkomstenbelasting de activa en passiva volgens goed koopmansgebruik gewaardeerd.

$\mathrm{Bij}$ de waardeering der activa moet in acht worden genomen hetgeen art. 10, (2) bepaalt:

.,De activa worden ten minste op de werkelijke aanschaffings- of voortbrengingskosten gewaardeerd. Bij de waardeering van zaken, welke voor de uitoefening van het bedrijf of beroep worden gebruikt, wordt echter rekening gehouden met de volgens artikel 11 te verrichten afschrijvingen. Waardeering op een lager bedrag dan uit de beide vorige zinnen voortvloeit, is slechts geoorloofd, voor zoover en zoolang de bedrijfswaarde van het voorwerp der waardeering aantoonbaar lager is. Onder bedriifswaarde wordt verstaan de waarde, welke een verkrijger, bij overneming van het geheele bedrijf of beroep, zou toekennen aan het afzonderlijke activum, indien hij zou uitgaan van de overnemingswaarde van het ge heel en voornemens zou zijn, de uitoefening van het bedrijf of beroep voort te zetten".

Hieruit kan worden geconcludeerd, dat, indien de aanschaffingskosten van gekochte goederen hooger zijn dan de vervangingswaarde, tegen vervangingswaarde zal mogen worden gewaardeerd en indien de voortbrengingskosten van zelf geproduceerde goederen lager zijn geworden, ook met deze lagere kosten rekening zal mogen worden gehouden. Immers bij overneming van het bedrijf zal aan ,, het afzonderlijke activum" geen hoogere waarde worden toegekend dan de marktwaarde of de voortbrengingskosten op dat tijdstip.

Wat de bedrijfsmiddelen betreft, die voor de uitoefening van het bedrijf worden gebruikt, zal men om dezelfde reden, indien de vervangingswaarde lager is dan de aanschaffings- of voortbrengingskosten op grondslag van de vervangingswaarde mogen waardeeren.

Met betrekking tot de passiva vermeldt het Besluit - art. 10, (3):

,Als aftrekbare passiva komen slechts in aanmerking verplichtingen, welke tegenover bepaalde natuurlijke of rechtspersonen bestaan of welke plegen te ontstaan uit reeds bestaande rechtsverhoudingen."

Voor belastingplichtigen, die niet regelmatig boekhouden vermeldt art. $12,(7)$ :

,"Ter zake van het vormen of vergrooten van een reservefonds of voor interest van eigen kapitaal is geen aftrek toegelaten."

De mogelijkheid tot reservevorming is dus wel zeer gering. Alleen de woorden, verplichtingen, welke plegen te ontstaan uit reeds bestaande rechtsverhoudingen, bieden eenige ruimte voor reservevorming. De toekomstige rechtspraak zal moeten leeren in hoeverre hiertoe aanleiding kan bestaan. In ieder geval staat wel vast, dat de Winstbelasting veel meer rekening houdt met risico's, die het bedrijfsleven heeft te dragen.

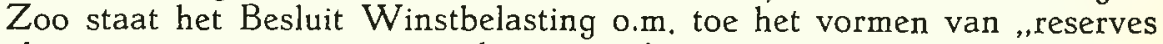
als voorziening tegen aanwijsbare risico's en reserves met eene bestemming van soortgelijken aard". 
Ten aanzien van de afschrijving op bedrijfsmiddelen, die in het bedrijf worden gebruikt, vermeldt art. 11, (1):

.,Bij gebouwen en andere zaken, welke voor de uitoefening van het bedrijf of beroep worden gebruikt en welker gebruik langer dan een jaar pleegt te duren, kan telken jare een zoodanig gedeelte op de werkelijke aanschaffings- of voortbrengingskosten als afschrijving in aftrek worden gebracht als overeenkomst met het aandeel van het jaar in de waardevermindering tusschen het begin van het jaar en het einde van den gebruiksduur".

Volgens den inhoud van dit artikel kan afschrijving plaats hebben alleen op de aanschaffings - of voortbrengingskosten, Afschrijven over de vervangingswaarde, noodzakelijk geworden bij aanzienlijke waardestijging van het bedrijfsmiddel, kent het Besluit Inkomstenbelasting niet.

Ten slotte dient nog vermeld te worden, dat het woord ,"gebruiksduur" aanleiding kan geven tot de opvatting, dat alleen een technische afschrijving volgens de geschatte gebruiksduur kan worden toegestaan.

De bepalingen van het Besluit op de Inkomstenbelasting 1941 leiden - gezien de grondslagen voor de winstbelasting - tot de conclusie, dat de vaststelling van de bedrijfswinst aan zoodanige grenzen is gebonden, dat de fiscale winst belangrijk kan afwijken van de winst. die met in acht neming van bedrijfseconomische beginselen wordt bepaald.

\section{DE OMZETSNELHEID IN DEN DETAILHANDEL}

door Dr F. L. van Muiswinkel

\section{Inleiding.}

In ons artikel over de Calculatie in den Detailhandel (zie April nr. M.A.B.) vestigden wij o.m. de aandacht op de omzetsnelheid als één der maatstaven voor den kostenopslag. In het onderhavige artikel willen wij de beteekenis van de omzetsnelheid in den detailhandel nader bezien.

Achtereenvolgens moge daarbij worden aangetoond:

a. dat men zich bij het calculeeren van den kostenopslag moet baseeren op de omzetsnelheid van elk artikel afzonderlijk:

b. dat men door het deelen van de (herleide) geldswaarde van den totalen voorraad van alle artikelen op den (herleiden) geldomzet niet vindt de omzetsnelheid van den voorraad, doch de omloopsnelheid van het in den voorraad gestoken kapitaal.

Tenslotte zullen wij nog eenige opmerkingen maken over

c. omzetsnelheid en debiteurensaldo, en

d. het verband tusschen omzetsnelheid, omloopsnelheid, bruto winst en bedrijfskosten.

a. De omzetsnelheid per artikel.

Onder de omzetsnelheid verstaat men het aantal malen, dat de voorraad in een bepaalde periode (b.v. een jaar) is omgezet. Hoe hooger de omzetsnelheid, hoe geringer de interestfactor in verhouding tot den om - 